\title{
Food globalisation in prehistory: The agrarian foundations of an interconnected continent
}

\author{
Elsley Zeitlyn Lecture on Chinese Archaeology and Culture
}

Read 17 February 2015

\section{MARTIN JONES \\ with \\ HARRIET HUNT, CATHERINE KNEALE, EMMA LIGHTFOOT, DIANE LISTER, XINYI LIU, and GIEDRE MOTUZAITE-MATUZEVICIUTE}

Abstract: This article explores grain crop movement across prehistoric Eurasia. It draws on evidence from archaeobotany, stable isotope studies, and archaeogenetics to date and map the process of food globalisation, and relate it to human consumption, culinary practice and crop ecology. It reviews the findings of a project funded by the European Research Council, Food Globalization in Prehistory, placed in the context of the expansion of research across Eurasia over the last two decades. This major episode of food globalisation has discernible roots in the third millennium BC, which during the second millennium BC fully crystallises into a contiguous network following foothills and mountain corridors with the Himalayan uplift at its heart. We infer a significant bottom-up component to the establishment of this pattern, which serves as a prelude for the top-down valley-bottom agrarian systems that recur from the second millennium $\mathrm{BC}$ onwards.

Keywords: Panicum, Setaria, Triticum, Hordeum, Neolithic, Bronze Age, Asia

In northern China, spring is welcomed with a light white steamed bread known as huamo (colourful bread), which local women decorate just as their mothers and grandmothers have done before them. Several thousand kilometres to the west, the same season is welcomed with the ancient festival of Maslenitsa (butter week). For this, just as their forbears have for centuries, Russian women prepare unleavened buckwheat pancakes (blini) that are round and golden like the sun.

These two springtime celebrations share a geographical paradox. In the west, the golden colour of the blini is achieved by using buckwheat, a crop whose origins are in 
the east, while over in the east, the fluffy white texture of the huamo requires bread wheat, whose origins are in the west. When did that changeover happen? When and how did a Chinese plant (buckwheat) become deeply embedded in a Russian cuisine, just as a west Asian crop (bread wheat) became deeply embedded in a Chinese cuisine?

An obvious candidate is the 'Silk Road', the series of trade routes across Eurasia historically documented from the first millennium BC. We might push the origins of those trade routes back into the latter part of the second millennium $\mathrm{BC}$, by reference to the archaeology of horse management and metallurgy. But archaeobotanical evidence from the crops themselves suggests an earlier date still. This paper explores three forms of evidence - archaeobotany, stable isotope studies of early diet, and genetic analyses of crop diversity - which together have cast a great deal of light on a highly significant episode of food globalisation in prehistory.

A decade ago, one of the current authors (MJ) published a series of maps that are now both out of date and in need of revision (Jones 2004). They cited published claims for three crops whose origin was most plausibly in China but were found at early dates in the west. Alongside buckwheat were the two Asian millets: broomcorn and foxtail. The paper offered a few speculations on how that might have come about. In the year after publication, the speculations led to the first of many fieldtrips to China by various of this paper's authors to understand more about the archaeobotany of these crops. That first fieldtrip proved to be timely.

Even as MJ and XL prepared the itinerary, news was coming to light of a large amount of new Chinese evidence, largely instigated by the introduction of flotation techniques to a very wide range of archaeological sites across the country by Professor Zhijun Zhao of the Chinese Academy of Social Sciences (Zhao 2004; 2005). His early flotation results indicated two things. First, the site of Xinglonggou in Chifeng was significantly enriching the records of early millet in North China. Second, in addition to these millets, there were early prehistoric records of wheat and barley in China (Zhao 2004). These records were dating back to the third millennium BC.

North China and west Asia were not the only two regions experiencing intercontinental crop movement in prehistory. Archaeobotany has similarly seen significant growth in Africa and south Asia, and these regions too display patterns of globalisation (Boivin et al. 2014; Fuller \& Rowlands 2011; Pokharia et al. 2014; Weber 1998). African crops, in particular sorghum, and also the African millets-pearl and finger millet-were recorded from India by 2000 BC (Pokharia et al. 2011; Reddy 1997; Saraswat 1986; Weber 1991), where they joined both the established indigenous millets (Weber 1991; 2003), as well as broomcorn and foxtail millet introduced from China at a similar period (Chanchala 1994; Constantini 1979; Reddy 1997). Northwest India, the focus of Harappan cultures was emerging as an agrarian crossroads in which 
African, west Asian and east Asian crops were appearing alongside indigenous crops in a truly global mix by 1500 BC (Fuller 2011).

Much archaeobotanical data was coming together, with very little, in terms of conventional archaeological evidence, within which it could be contextualised. The Trans-Eurasian Exchange proposed by Andrew Sherratt (2006) encapsulated a significant period of artifact movement in the second half of the second millennium BC. By around $1200 \mathrm{BC}$, such a pattern is clearly seen in metalwork technologies shared across the north of Eurasia, and of the horse-harnessing and carriage technology that accompanied it (cf. Anthony 1997). The 'horse-riders of the steppes' provided a useful template for globalisation that predated the historic Silk Road, but did not quite come early enough to account for the archaeobotanical evidence. By $1600 \mathrm{BC}$, a great deal of such evidence exists, and it goes back further still. The mid-third millennium BC contains a number of significant records, including some early wheat records in the east, and a series of sites midway around Begash in southeastern Kazakhstan, where in-depth research by Michael Frachetti, Robert Spengler and colleagues has found eastern and western crops together from about $2400 \mathrm{cal}$ BC.

MJ's 2004 paper was followed in 2008 by a much more systematic study of published records of broomcorn millet, noting records of this crop in western contexts with published dates preceding $5000 \mathrm{BC}$ (Hunt et al. 2008). While we have subsequently queried those earliest dates (Motuzaite Matuzeviciute et al. 2013) it seemed at the time as if the start of food globalisation across Eurasia might have preceded the metallurgy/horse-bridling horizon by several millennia.

It was a moment for fairly open speculation. In the context of the early Chinese wheat, Zhijun Zhao (2011) suggested three candidates for a trans-Asian route. One was a proto silk route - essentially the topographically most convenient and economic land routes between east and west. Another drew from discussions of shared traditions of pastoralism, horse management and metallurgical traditions and was characterised as the northern steppe route. The third related to the near-coastal position of some of the earliest wheat appearing in the east, raising the possibility of a sea route. These three potential routes presented a set of initial hypotheses we could explore through a combination of methodologies - namely, archaeobotany, stable isotope studies and archaeogenetics - to assess the plausibility of all or none of these routes. We achieved these through a five-year research programme sponsored by the European Research Council entitled Food Globalisation in Prehistory or 'FOGLIP' (cf. Jones et al. 2011).

Thanks to the growth of global research over this period, the first of these methodological strands of the FOGLIP project could be targeted towards the key gaps left by the growing momentum of archaeobotanical research across the Old World. Exploration of Zhao's coastal route was greatly facilitated by work of Fuller 
and colleagues along the southern latitudes, and of the Sealinks project (cf. Boivin et al. 2014). Exploration of proto silk routes was similarly facilitated both by the expansion of Chinese archaeobotany, and by the work of Frachetti, Spengler and colleagues along the foothills of southern Kazakhstan and Kyrgyzstan (Frachetti et al. 2010; Spengler 2013; Spengler et al. 2014a;. 2014b; 2014c; Spengler III 2015). Less well explored was Zhao's northern steppe route, for which a number of archaeological sites were recorded, but in which archaeobotanical techniques had not generally been applied.

In the context of domesticated resources, a site of great significance along the northern steppe route is Botai, near to Saumalkol in North Kazakhstan. Here a series of studies have connected the region to the deep history of interaction with horses and their domestication (Anthony 1997; Benecke \& von den Driesch 2003; Levine 1999; Olsen 2003; Outram et al. 2009). Given the subsequent historical relationship between equine pastoralists and short-season millet cultivation, it seemed an obvious site to explore for early evidence of millet which had spread westwards from its Chinese source. However, flotation had not been undertaken on the site until 2011, when the current authors in collaboration with Victor Zaibert and Alan Outram excavated a new house circle and its environs, specifically to carry out an intensive program of flotation (Lightfoot et al. in prep).

That season of flotation generated potentially edible plant remains, including Chenopodium and Polygonum genus plant seeds and unidentified plant family tubers. (Lightfoot et al. in prep.). However, cereals were completely absent. The pattern has been corroborated on other northern steppe route locations, particularly the Bronze Age Altai Mountain sites explored by Hanks (2010) and in the Bronze Age Urals by Rühl et al. (2015) and Lebedeva (1996). These too feature wild plants that may conceivably have contributed to human diet, but no cereals. If we combine these negative data with stable isotope results reflecting the emergence of millet consumption in the north, it would seem that the agriculture along the northern steppe route is essentially a first millennium BC phenomenon (Matuzeviciute et al. 2015a), derived from a series of northward expansions from an already-established zone of agrarian connectivity to the south.

Looking to the south, the zone that clearly emerges from archaeobotanical analysis as a significant belt is what Frachetti has described as the 'Inner Asian Mountain Corridor' (Frachetti 2012). Essentially, a foothill region below the mountain and overlooking the plain has provided direct evidence of the crop interchange in several places (Doumani et al. 2015; Matuzeviciute et al. 2015b; Rouse and Cerasetti 2014; Spengler and Willcox 2013; Spengler et al. 2013; 2014a; 2014b; 2014c). The Begash site is key, as are data that Willcox (1991) published from Shortugai. We can extend Frachetti's core corridor to encompass regions both to the southwest to Afghanistan and 
Turkmenistan, and to the southeast to Xinjiang and Gansu in China (Liu et al. 2014; Rouse and Cerasetti 2014; Spengler et al. 2013; 2014c).

While the archaeobotanical evidence provides locations, dates and site contexts, it stops short of elucidating the place of these crops in the human food chain. For that, the evidence of stable carbon isotopes is invaluable. Two of the key crops moving westward from China (broomcorn and foxtail millet) are $\mathrm{C}_{4}$ plants that leave an isotopic signature throughout the food chain which is distinctive from that left by west Asian crops moving east (all $\mathrm{C}_{3}$ plants). ${ }^{1}$ So movements in both directions can be to some extent quantified and related to particular consumers. In this way, it can be seen that the westward movement of Asian millets, and the eastward movement of Fertile Crescent cereals follow different patterns.

The consumption of millet in any quantity in western Eurasia would appear, on the basis of stable isotopic evidence, to be sporadic in prehistory (Lightfoot et al. 2013). While there are a few individuals with isotopic evidence for millet consumption in the third millennium, it is not until the second millennium that millet consumption can be seen on any discernable scale. Even then, however, in 2013 there were only 12 known sites with isotopic evidence for human millet consumption - some of which represent whole communities and others only one or two individuals consuming millet. This is not to say that the majority of people did not eat millet at this time, just that they did not consume it in large enough quantities for it to affect their stable isotope ratios - certainly they did not consume millet regularly enough for it to be considered a staple food. This is in marked contrast to the pattern of novel grain crops in the east.

An important topographic feature channeling eastward movement is the Hexi corridor, bounded to the north by the Gobi Desert, to the south by the Tibetan Plateau, and leading towards the Loess Plateau and Central Plains of China. A series of cemeteries of the Qijia culture (c. 2200-1600 BC) provide an insight into the movement of Fertile Crescent crops into the millet zone of the east.

In seven cemetery sites studied by Liu et al. (2014), carbon isotope enrichment data cluster into two distinct groups. The individuals in one group correspond to a diet dominated by $\mathrm{C}_{4}$ plants (millet), while those in the other group correspond to a mixed diet containing $\mathrm{C}_{3}$ and $\mathrm{C}_{4}$ plants, likely wheat and/or barley and millet, respectively. The first group includes all of the individuals from two sites dating to before $1900 \mathrm{BC}$. The second group contains virtually all of the individuals from five sites dating to after $1900 \mathrm{BC}$. The seven sites are internally consistent; it would appear that the entire community at each site shared a dietary pattern in common. There are no evident 'trail-blazers' in the novel post-1900 BC pattern. Liu and Jones (2014)

${ }^{1}$ Land plants can be divided into two groups according to how they fix carbon from the atmosphere. 
inferred that this considerable agrarian change was a 'bottom-up' change, in which the whole community was engaged from the start, rather than an elite-led process. The 'tidal wave' of western crops after 1900 BC certainly constituted an agricultural revolution in the Hexi corridor.

Whatever the stimuli to that revolution, its consequences become clear as one moves from the Hexi corridor to the Loess Plateau, and the Yellow River running through it. The hilly flanks of the wider Yellow River catchment had formed the focus of millet exploitation all the way from Xinle, through Xinglonggou, Cishan, and Peiligang to Dadiwan (Liu et al. 2009). The North Chinese archaeobotanical record allows us to follow the development of millet farming into the upper reaches of that catchment.

Up until the appearance of $\mathrm{C}_{3}$ crops along the Hexi corridor, millet farming is attested in many sites up to an altitude of $2500 \mathrm{~m}$ above sea level, here reaching the ecological limit for millet growth (cf. d'Alpoim Guedes \& Butler 2014). In the centuries immediately after the Hexi corridor appearance, wheat and barley are found within in a similar altitudinal range. Thereafter, that range expands. After 1600/1500 BC, barley attains unprecedented altitudes, above $2500 \mathrm{~m}$ and at eight sites in Qinghai between 3000 and $3500 \mathrm{~m}$ (d'Alpoim Guedes et al. 2015; Chen et al. 2015). The novel ecology of barley in particular allowed farmers to reach their highest altitudes. In the subsequent millennium, there would be equivalent spreads to northerly latitudes. All this was happening even as climatic proxies indicate that environments at high altitudes and in the far north were actually getting colder.

Significant changes in temperature are only one of the ecological challenges to which crop plants are exposed when moved away from their core locations. Desiccation, waterlogging and exposure to wind and UV radiation may all prevail in ways to which the plant has not been accustomed. A number of these can, to some extent, be mitigated by the farmer, who will, however, have greater difficulty mitigating the pattern of the seasons.

Various stages in a plant's life cycle are triggered by seasonality cues. These include fluctuations in day length and temperature. The stages controlled may include breaking of seed dormancy, germination and the initiation of flowering. Changes in either the latitude or the altitude at which a crop is cultivated can change these seasonality triggers, such that the plant's life cycle is removed from the conditions of light, temperature and water availability to which it is adapted. A consequence of the food globalisation process, and the genetic response of crops to these changed conditions, is that the farmer, rather than the ambient seasonal cycle, subsequently determines and maintains the schedule of crop growth. This has been most clearly documented in the case of a flowering time gene in barley, Ppd-H1 (Jones et al. 2008; Lister et al. 2009). We can infer that the deactivation of seasonality-response genes will be a recurrent feature of crops taken outside their original zone of adaptation. 
Both seasonality response and ecological response will be recurrent themes in the evolutionary dimension of food globalisation. It would also appear there is some active selection for what might be described as culinary genes, such as those that control the level of amylose in starchy crops.

The presence of low amylose levels in starchy foods forms a recurrent and deepseated theme in east Asian cuisine. The effect of low grain amylose (leaving the branched molecule amylopectin as the dominant starch) gives the foodstuffs a distinctly 'sticky' texture, which is much favoured in a number of east Asian cultures. Fuller and Rowlands (2011) argue that this sticky cuisine is associated with a range of other wet, soupy and wholegrain cuisines of which the material culture proxy may be the ceramic vessel. Wet and sticky cuisine corresponds geographically to a region in which ceramic vessels date back to the Upper Palaeolithic, suggesting this range of cuisines may be ancient. Parallel arguments might suggest that a western grinding/ dough preparation/ baking cuisine may be similarly ancient.

One aspect of the great antiquity of sticky cuisine emerges in the genetic patterns within one of the crops affected: broomcorn millet. Hunt et al. (2011; 2013). analysed microsatellite diversity in Panicum miliaceum landraces, and inferred genetic structure within the domesticated crop. The resulting data classified the landraces into six genetic groups, whose distributions overlapped in the region of north China in which early millet sites were found.

The same suite of accessions was screened for functionality of the 'waxy gene', which controls the amylose/amylopectin balance of the grain starches, such that a sticky foodstuff is produced (Hunt et al. 2010; 2013). Because of the complex genome of broomcorn millet, two genes are involved in controlling the grain starch phenotype in this species, but they have unequal roles. Not surprisingly, the sticky-starch variant of the principal gene is found primarily in those genetic groups (defined by microsatellite diversity) with an east Asian distribution, coinciding with the regions in which a long history of sticky cuisine is well attested. A second gene also has a sticky variant, but is a supporting player and the sticky-starch phenotype is not expressed unless the principal gene is also of the sticky type. In contrast to the patterns of the principal gene, the knocked-out (sticky) forms of the supporting gene are widely distributed throughout the genetic groups present in western Eurasia. It is likely that the genetic changes giving rise to sticky forms occurred in Chinese varieties prior to the westward spread of millet, and those in the major gene were selected against outside the sticky cuisine zone, while those in the supporting gene were able to spread throughout Eurasia undetected by selection.

While the non-sticky forms of millet are the only types adopted in the west, various western crops moving east, including barley, have given rise to sticky forms, no doubt as a consequence of culinary selection. In both east and west, culinary choices proved 
more conservative than the choice of crops, exotic alongside traditional, during the period of food globalisation.

This conservative tendency can also be observed in other aspects of the crop: for example, preferred grain size. The western crops-wheat and barley-have large grains compared with their eastern counterparts-broomcorn, foxtail, buckwheat and even rice. As the eastern cuisine, as well as being wet and sticky, is also predominantly wholegrain, the size of the grain is apparent to the diner. The familiarity with small grains manifests itself in a selection for size reduction in western grains, such that wheat grains in particular in Chinese prehistory are a fraction of the size of their western counterparts (Liu et al. in prep). So food globalisation took place in the context of culinary conservatism. Crop plants moving west had any sticky gene variants selected against, and were folded into a grinding/griddling or baking cuisine. Crop plants moving east were selected for small grain size and sometimes for 'stickiness'.

Returning to the environmental context of food globalisation, the two-dimensional map, with eastward and westward movement across it, at a certain point constrains our analysis and interpretation. In reality, the landscape is three-dimensional, and the predominant axes of human mobility are upstream and downstream. Eurasia is dominated by the Himalayan uplift, and a series of mountain corridors that connect with, or radiate from that uplift. The foothill chains along the various river catchments that connect with that mountain system have repeatedly proved to be key for the location of early farming sites, providing a conceptual connection between the 'Hilly Flanks' of the southwest Asian Fertile Crescent, the 'Inner Asian Mountain Corridor', and the foothills of China (Braidwood \& Braidwood 1969; Frachetti 2012; Liu et al. 2009). The earliest farming settlements in each region appear along elevated locations at the edge of river catchments, sometimes at a considerable distance from the valley bottom below.

In the course of visiting many of these regions in the context of FOGLIP research, we had the opportunity to speak to local farmers, both young and old. Those of sixty years of age, or younger, had grown up in the context of large-scale irrigation schemes that effectively tamed the valley bottom and released its intensive potential. The farming systems with which they were familiar depended on those schemes, which were often instigated or maintained by some regional or national state initiative. We also had the opportunity to speak to some elderly farmers, some in their nineties, who remembered farming ways preceding the great irrigation installations of the 20th century. They were able to reminisce about foothill farming.

$\mathrm{Mr}$ and Mrs Zhu, from Balikun in northern Xinjiang grew up in a community along the northern foothills of the Tianshan range, which was often regarded as 'pastoralist' and indeed animals were an important and central part of the community's economy. 
However, they were also able to list from memory a series of crops they grew before the mid-20th-century valley bottom irrigation schemes, and fed with water from the mountain. In contrast to the later irrigation installations, they steered and modified mountain streams by moving stones around in the landscape. They used a variety of animals for that purpose, including mules and camels, but also goats. The use of goats as a draft animal allowed them to divert water towards their foothill plots all the way from source, where it lay in the form of montane ice and snow.

The key virtue of this high-altitude water use was that it was dependable and could be achieved by small family units, although it requires effort and ingenuity. The water in the valley bottom could indeed by plentiful in certain seasons, but its use as a dependable source for agriculture required an elaborate social contract, certainly with neighbours upstream and downstream, and by implication any hierarchy enforcing and maintaining the collective contract.

At a certain point those contracts come into place, and farming communities come down to fully exploit the valley bottoms for agriculture. With them, they bring downhill the local crops familiar to each region, but in addition the exotic crops that have moved from some distant landscape as part of the process of food globalisation. One most interesting aspect of these exotic crops is the recurrent possibility that, in the process of their global movement, their environmental and seasonality response genes have been deactivated.

These non-responsive crops present a novel option to the farmer. The large-scale irrigation systems mitigate seasonal uncertainty over water supply, and associated deeper cultivation effectively mitigates the soil environment of soil temperate through the year. In this more controlled environment, the non-responsive crops can be planted and grown in a season chosen by the farmer, rather than any season predetermined by the crop's genes. Multi-cropping becomes possible, in turn enabling the support of the stratified societies controlling the agrarian social contract.

In summary, the food globalisation phenomenon seems best explained by a bottom-up process that incrementally got underway during the course of the third millennium BC, and intensified during the second (Liu \& Jones 2014). The first stages could have been enacted by people moving with their animals, seeking grass on a regular basis, as well as intermittently seeking marriage partners and other resources. Frachetti $(2006 ; 2008)$ has modelled such a process and given an indication of the way in which networks of extensive material culture flow can result. By the middle of the second millennium BC, such a network had crystallised across Eurasia, following a hilly perimeter of the Himalayan uplift, and extending from there across a series of foothill chains and mountain corridors. The bottom-up nature of this process is reflected in various ways; the primacy of the foothill locations, the isotopic record of mass transformation in the Hexi corridor and the conservatism of regional culinary practice. 
While we are proposing a significant bottom-up element to this initial process of food globalisation, its consequence as the second millennium progressed was to greatly facilitate top-down stratified societies. Recurrent themes of these societies are: largescale valley-bottom water management schemes; intensive deep cultivation; and multiple cropping, the last changing the productivity of individual fields and thus facilitating a non-agrarian social stratum determining the social contract that underpins the use of valley-bottom water. A significant element of multiple cropping is the availability of plants that can grow in a season chosen by the farmer, rather than by annual climatic cycles. Those plants became more readily available as a consequence of deeper, distinct episodes in the long process of food globalisation in prehistory.

\section{Acknowledgements}

This paper relates to the 2015 Elsley Zeitlyn Lecture, delivered by the lead author at the British Academy in London, Washington University in St. Louis, and Peking University in Beijing. Gratitude is extended to the Academy and all three hosts. The authors are moreover grateful to the European Research Council, under grant 249642 (FOGLIP), the Leverhulme Trust, under grant f/09717/C (PPAC), Darwin College, National Project of Philosophical and Social Sciences of China, under grant 12\&ZD151, and the European Union Structural Funds project, Postdoctoral Fellowship Implementation in Lithuania, for financial support. We are also extend our gratitude to members of the FOGLIP team for many discussions leading to this manuscript.

\section{REFERENCES}

Anthony, D. (1997), 'Current Thoughts on the Domestication of the Horse in Asia', South Asian Studies, 13: 315-318. http://dx.doi.org/10.1080/02666030.1997.9628546

Benecke, N. \& von den Driesch, A. (2003), 'Results of the Study on Horse Bones from Botai (Northern Kasakhstan)', in M. Levine, Y. Rassamakin, A. Kislenko \& N. Tatarintseva (eds) Late Prehistoric Exploitation of the Eurasian Steppe (Cambridge, McDonald Institute for Archaeological Research), 69-82.

Boivin, N., Crowther, A., Prendergast, M. \& Fuller, D.Q. (2014), 'Indian Ocean Food Globalisation and Africa', African Archaeological Review, 31(4):547-581.

Braidwood, L. \& Braidwood, R.J. (1969), 'Current Thoughts on the Beginnings of Food Production in South-western Asia', Mélanges Université St-Joseph, 45(48):149-155.

http://dx.doi.org/10.1007/s10437-014-9173-4

Chanchala, S. (1994), 'Harappan Plant Economy of Kutch, Gujarat', Geophytology, 23(2):227-233.

Chen, F., Dong, G., Zhang, D., Liu, X., Jia, X., An, C.B., Ma, M., Xie, Y.W., Barton, L., Ren, X., Zhao, Z., Wu, X. \& Jones, M.K. (2015), 'Agriculture Facilitated Permanent Human Occupation of the Tibetan Plateau after 3600 BP', Science, 347: 248-250 http://dx.doi.org/10.1126/science. 1259172

Costantini, L. (1979), 'Plant Remains at Pirak', in J.F. Jarrige, J.F. Enault \& M. Santoni (eds), Fouilles de Pira (Paris, Diffusion De Boccard), 326-333. http://dx.doi.org/10.1073/pnas. 1423708112 
d'Alpoim Guedes, J., Hongliang Lu, Hein, A. \& Schmidt, A., (2015), 'Early Evidence for the Use of Wheat and Barley as Staple Crops on the Margins of the Tibetan Plateau', Proceedings of the National Academy of Sciences, 112(18):5625-30. http://dx.doi.org/10.1073/pnas.1423708112

d'Alpoim Guedes, J. \& Butler, E. (2014), 'Modeling Constraints on the Spread of Agriculture to Southwest China with Thermal Niche Models', Quaternary International, 349:29-41. http://dx.doi.org/10.1016/j.quaint.2014.08.003

Doumani, P.N., Frachetti, M.D., Beardmore, R., Schmaus, T.M., Spengler, R.N. \& Mar'yashev, A.N. (2015), 'Burial Ritual, Agriculture, and Craft Production among Bronze Age Pastoralists at Tasbas (Kazakhstan)', Archaeological Research in Asia, 1:17-32. http://dx.doi.org/10.1016/j.ara.2015.01.001

Frachetti, M.D. (2006), 'Digital Archaeology and the Scalar Structure of Space and Time: Modeling Mobile Societies of Prehistoric Central Asia', in T. Evans \& P. Daly (eds) Digital Archaeology (London, Routledge), 128-47.

Frachetti, M.D. (2008), Pastoralist Landscapes and Social Interaction in Bronze Age Eurasia (Berkeley, CA, University of California Press).

Frachetti, M.D. (2012), 'Multiregional Emergence of Mobile Pastoralism and Non-uniform Institutional Complexity across Eurasia', Current Anthropology, 53(1):2-38. http://dx.doi.org/10.1086/663692

Frachetti, M.D., Spengler, R.N., Fritz, G.J. \& Mar'yashev, A.N. (2010), 'Earliest Direct Evidence for Broomcorn Millet and Wheat in the Central Eurasian Steppe Region', Antiquity, 84(326): 993-1010. http://dx.doi.org/10.1017/S0003598X0006703X

Fuller, D. \& Rowlands, M. (2011), 'Ingestion and Food Technologies: Maintaining Differences over the Long-Term in West, South and East Asia.', in J. Bennett, S. Sherratt \& T.C. Wilkinson (eds), Interweaving Worlds-Systematic Interactions in Eurasia, 7th to 1st Millennia BC. Essays from a Conference in Memory of Professor Andrew Sherratt (Oxford, Oxbow Books), 37-60.

Hanks, B. (2010), 'Archaeology of the Eurasian Steppes and Mongolia', Annual Review of Anthropology, 39:469-87. http://dx.doi.org/10.1146/annurev.anthro.012809.105110

Hunt, H.V., Vander Linden, M., Liu X., Motuzaite-Matuzevicuite, G. \& Jones, M.K. (2008), 'Millets across Eurasia: Chronology and Context of Early Records of the Genera Panicum and Setaria from Archaeological Sites in the Old World', Vegetation History and Archaeobotany, 17:S5-S18. http://dx.doi.org/10.1007/s00334-008-0187-1

Hunt, H.V., Denyer, K., Packman, L.C., Jones, M.K. \& Howe, C.J. (2010), 'Molecular Basis of the Waxy Phenotype in Broomcorn Millet (Panicum miliaceum L.)', Molecular Biology and Evolution, 27:1478-94. http://dx.doi.org/10.1093/molbev/msq040

Hunt, H.V., Campana, M.G., Lawes, M.C., Park, Y.J., Bower, M.A., Howe, C.J. \& Jones, M.K. (2011), 'Genetic Diversity and Phylogeography of Broomcorn Millet (Panicum miliaceum L.) across Eurasia', Molecular Ecology, 20:4756-71. http://dx.doi.org/10.1111/j.1365-294X.2011.05318.x

Hunt, H.V., Moots, H.M., Graybosch, R.A., Jones, H., Parker, M., Romanova, O., Jones, M.K., Howe, C.J. \& Trafford, K. (2013), 'Waxy Phenotype Evolution in the Allotetraploid Cereal Broomcorn Millet: Mutations at the GBSSI Locus in their Functional and Phylogenetic Context', Molecular Biology and Evolution, 30:109-22. http://dx.doi.org/10.1093/molbev/mss209

Jones, H., Leigh, F.J., Mackay, I., Bower, M.A., Smith, L.M.J., Charles, M.P., Jones, G., Jones, M.K., Brown, T.A. \& Powell, W. (2008), 'Population Based Re-sequencing Reveals that Flowering Time Adaptation of Cultivated Barley Originated East of the Fertile Crescent', Molecular Biology and Evolution, 25:2211-19. http://dx.doi.org/10.1093/molbev/msn167

Jones, M.K. (2004), 'Between Fertile Crescents: Minor Grain Crops and Agricultural Origins', in M.K. Jones (ed.) Traces of Ancestry: Studies in Honour of Colin Renfrew. (Cambridge, McDonald Institute for Archaeological Research), 127-35.

Jones, M.K., Hunt, H., Lightfoot, E., Lister, D., Liu, X. \& Motuzaite-Matuzeviciute, G. (2011), 'Food Globalisation in Prehistory', World Archaeology, 34(4):665-75.

http://dx.doi.org/10.1080/00438243.2011.624764 
Lebedeva, E.Y. (1996), 'O zemledelii v stepyakh i lesostepyakh Vostochnoi Evropy v epokhu bronzy', Uralskoe arkheologicheskoe soveshchanie XIII(1):53-5.

Levine, M.A. (1999), 'Botai and the Origins of Horse Domestication', Journal of Anthropological Archaeology, 18:29 -78. http://dx.doi.org/10.1006/jaar.1998.0332

Lightfoot, E., Liu, X. \& Jones, M.K. (2013), 'Why Move Starchy Cereals? A Review of the Isotopic Evidence for Prehistoric Millet Consumption Across Eurasia', World Archaeology, 45(4):574-623. http://dx.doi.org/10.1080/00438243.2013.852070

Lightfoot, E., Motuzaite-Matuzeviciute, G., Liu, X., Outram, A., Zaibert, V., Zakharov, S. \& Jones, M.K. (in prep.), 'Archaeological Investigations of a Pit House and Other Features at Botai, Kazakhstan', Internet Archaeology.

Lister, D.L., Thaw, S, Bower, M.A., Charles, M., Jones, G., Jones, H., Howe, C.J., Brown, T.A. \& Jones, M.K. (2009), 'Latitudinal Variation in a Photoperiod Response Gene in European Barley: Insight into the Spread of Agriculture from Historic Specimens', Journal of Archaeological Science, 36:1092-8. http://dx.doi.org/10.1016/j.jas.2008.12.012

Liu, X. \& Jones, M.K. (2014), 'Food Globalization in Prehistory: Top Down or Bottom Up?', Antiquity, 88:956-63. http://dx.doi.org/10.1017/S0003598X00050912

Liu, X., Hunt, H.V. \& Jones, M.K. (2009), 'River Valleys and Foothills: Changing Archaeological Perceptions of North China's Earliest Farms', Antiquity, 83:82-95. http://dx.doi.org/10.1017/S0003598X00098100

Liu, X., Lightfoot, E., O’Connell, T.C., Wang, H., Li, S., Zhou, L., Hu, Y., Motuzaite-Matuzeviciute, G. \& Jones, M.K. (2014), 'From Necessity to Choice: Dietary Revolutions in West China in the Second Millennium BC', World Archaeology, 46(5):661-80. http://dx.doi.org/10.1080/00438243.2014.953706

Matuzeviciute, G.M., Lightfoot, E., O’Connell, T., Voyakin, D., Liu, X., Loman, V., Svyatko, S., Usmanova, E. \& Jones, M.K. (2015a), 'The Extent of Cereal Cultivation among the Bronze Age to Turkic Period Societies of Kazakhstan Determined Using Stable Isotope Analysis of Bone Collagen', Journal of Archaeological Science, 59:23-34. http://dx.doi.org/10.1016/j.jas.2015.03.029

Matuzeviciute, G.M., Preece, R., Wang, S., Colominas, L., Ohnuma, K., Kume, S., Abdykanova, A. \& Jones, M.K. (2015b), 'Ecology and Subsistence at the Mesolithic and Bronze Age Site of Aigyrzhal-2, Naryn Valley, Kyrgyzstan', Quaternary International, 30:1-15. http://dx.doi.org/10.1016/j.quaint.2015.06.065

Motuzaite Matuzeviciute, G., Staff, R.A., Hunt, H.V., Liu, X \& Jones, M.K. (2013), 'The Early Chronology of Broomcorn Millet (Panicum miliaceum) in Europe', Antiquity, 87(338):1073-85. http://dx.doi.org/10.1017/S0003598X00049875

Olsen, S. (2003), 'The Exploitation of Horses at Botai, Kazakhstan', in M. Levine, C. Renfrew \& K. Boyle (eds), Prehistoric Steppe Adaptation and the Horse (Cambridge, McDonald Institute for Archaeological Research), 83-104.

Outram, A., Stear, N., Bendrey, R., Olsen, S., Kasparov, A., Zaibert, V., Thorpe, N. \& Evershed, R. (2009), 'The Earliest Horse Harnessing and Milking', Science, 323:1332-5. http://dx.doi.org/10.1126/science.1168594

Pokharia, A. K., Kharakwal, J.S., Rawat, Y.S., Osada, T., Nautiyal, C.M. \& Srivastava, A., (2011), 'Archaeobotany and Archaeology at Kanmer,a Harappan site in Kachchh, Gujarat: Evidence for Adaptation in Response to Climatic Variability', Current Science, 100(12):1833-46.

Pokharia, A., Kharakwal, J.S. \& Srivastava, A. (2014), 'Archaeobotanical Evidence of Millets in the Indian Subcontinent with Some Observations on their Role in the Indus Civilization', Journal of Archaeological Science, 42:442-55. http://dx.doi.org/10.1016/j.jas.2013.11.029

Reddy, S.N. (1997), 'If the Threshing Floor Could Talk: Integration of Agriculture and Pastoralism During the Late Harappan in Gujarat, India', Journal of Anthropological Archaeology, 16(2):62187. http://dx.doi.org/10.1006/jaar.1997.0308 
Rouse, L.M. \& Cerasetti, B. (2014), 'Ojakly: A Late Bronze Age Mobile Pastoralist Site in the Murghab Region, Turkmenistan', Journal of Field Archaeology, 39(1):32-50.

http://dx.doi.org/10.1179/0093469013Z.00000000073

Rühl, L., Herbig, C. \& Stobbe, A. (2015), 'Archaeobotanical Analysis of Plant Use at Kamennyi Ambar, a Bronze Age Fortified Settlement of the Sintashta Culture in the Southern Trans-Urals Steppe, Russia', Vegetation History and Archaeobotany, 24(3):413-26. http://dx.doi.org/10.1007/s00334-014-0506-7

Saraswat, K.S., (1986), 'Ancient Crop Economy of Harappans from Rohira, Punjab (ca. 2000-1700 BC)', Palaeobotanist, 35:32e38.

Sherratt, A. (2006), 'The Trans-Eurasian Exchange: The Prehistory of Chinese Relations with the West', in V. Mair (ed.) Contact and Exchange in the Ancient World (Honolulu: Univeristy of Hawai'i Press) 30-61.

Spengler, R.N. (2013), 'Botanical Resource Use in the Bronze and Iron Age of the Central Eurasian Mountain/Steppe Interface: Decision Making in Multiresource Pastoral Economies', PhD thesis, Washington University, St. Louis, MI

Spengler, R.N. \& Willcox, G. (2013), 'Archaeobotanical Results from Sarazm, Tajikistan, an Early Bronze Age Settlement on the Edge: Agriculture and Exchange', Environmental Archaeology, 18(3):211-21. http://dx.doi.org/10.1179/1749631413Y.0000000008

Spengler, R.N., Chang, C. \& Tourtellotte, P.A. (2013), 'Agricultural Production in the Central Asian Mountains: Tuzusai, Kazakhstan (410-150 bc)', Journal of Field Archaeology, 38(1):68-85. http://dx.doi.org/10.1179/0093469012Z.00000000037

Spengler, R.N., Cerasetti, B., Tengberg, M., Cattani, M. \& Rouse, L.M. (2014a), 'Agriculturalists and Pastoralists: Bronze Age Economy of the Murghab Alluvial Fan, Southern Central Asia', Vegetation History and Archaeobotany, 23(6):805-20.

http://dx.doi.org/10.1007/s00334-014-0448-0

Spengler, R.N., Frachetti, M.D. \& Domani, P.N. (2014b), 'Late Bronze Age Agriculture at Tasbas in the Dzhungar Mountains of Eastern Kazakhstan', Quaternary International, 348:147-57. http://dx.doi.org/10.1016/j.quaint.2014.03.039

Spengler, R.N., Frachetti, M.D., Doumani, P., Rouse, L., Cerasetti, B., Bullion, E. \& Mar'yashev, A.N. (2014c), 'Early Agriculture and Crop Transmission among Bronze Age Mobile Pastoralists of Central Asia', Proceedings of the Royal Society, 281:1-7.

http://dx.doi.org/10.1098/rspb.2013.3382

Spengler III, R.N. (2015), 'Agriculture in the Central Asian Bronze Age', Journal of World Prehistory, 28(3):215-53. http://dx.doi.org/10.1007/s10963-015-9087-3

Weber, S.A. (1991), Plants and Harappan Subsistence: An Example of Stability and Change from Rojdi, (Boulder, CO, Westview Press).

Weber, S. A. (1998), 'Out of Africa: The Initial Impact of Millets in South Asia', Current Anthropology, 39: 267-274. http://dx.doi.org/10.1086/204725

Weber, S.A. (2003), 'Archaeobotany at Harappa: Indications for Change', in S.A. Weber \& W.R. Belcher (eds), Indus Ethnobiology: New Perspectives from the Field. (Lanham, MD, Lexington Books), 175-98.

Willcox, G. (1991). 'Carbonised Plant Remains from Shortughai, Afghanistan', in J.M. Renfrew (ed.) New Light on Early Farming: Recent Developments in Palaeoethnobotany (Edinburgh, Edinburgh University Press), 139-153.

Zhao, Z. (2004), 'Cong Xinglonggou yizhi fuxuan jieguo tan Zhongguo beifang zaoqi nongye qiyuan wenti' (Addressing the origins of agriculture in north China based on the results of flotation from the Xinglonggou site), Dongya Guwu, 12:188-99. 
Zhao, Z. (2005), 'Zhiwu kaoguxue jiqi xin jinzhan (Achievements of paleoethnobotanical study in China)' Kaogu (Archaeology), 93:522-9.

Zhao, Z., (2011), 'New Archaeobotanic Data for the Study of the Origins of Agriculture in China', Current Anthropology, 52:S295-S304. http://dx.doi.org/10.1086/659308

Note on the lead author: Martin Jones is the first George Pitt-Rivers Professor of Archaeological Science at the University of Cambridge, and Vice-Master of Darwin College, Cambridge.

His early research concerned the development of later prehistoric and early historic agriculture in Europe, and the use of ecological indicators to understand the nature and form of early crop management. It was in the context of exploring the potential for combining archaeobotany and archaeogenetics in the study of agricultural development within Europe that he became interested in the early appearance in the European record of crops botanically associated with China, most notably the Asian millets.

Over the last decade, a series of projects funded primarily by the Wellcome Trust, the Leverhulme Trust, Darwin College, and the European Research Council has allowed Professor Jones to collaborate closely with Chinese colleagues to explore and analyse the evidence for Old World millet cultivation.

He has been awarded an Honorary Professorship at Chifung College, Inner Mongolia. He is a Special Research Advisor to the Institute of Archaeology, Chinese Academy of Social Sciences, and has been elected a member of the Academia Europaea.

His books include: The Molecule Hunt (Arcade Publishing, 2001), Traces of Ancestry (McDonald Institute for Archaeological Research, 2004) and Feast: Why Humans Share Food (Oxford University Press, 2007).

mkj12@cam.ac.uk

Co-author affiliations:

University of Cambridge: McDonald Institute for Archaeological Research

Dr Harriet Hunt

Ms Catherine Kneale

Dr Emma Lightfoot

Dr Diane Lister

Washington University in St Louis: Department of Anthropology

Professor Xinyi Liu

Vilnius University: Lithuanian Institute of History

Dr Giedre Motuzaite-Matuzeviciute 
To cite the article: Martin Jones, Harriet Hunt, Catherine Kneale, Emma Lightfoot, Diane Lister, Xinyi Liu, and Giedre Motuzaite-Matuzeviciute (2016), 'Food globalisation in prehistory: The agrarian foundations of an interconnected continent', Journal of the British Academy, 4: 73-87.

DOI $10.85871 / \mathrm{jba} / 004.073$

This article is licensed under a

Creative Commons Attribution-NonCommercial-NoDerivs 3.0 Unported License.

Journal of the British Academy (ISSN 2052-7217) is published by

The British Academy - the national academy for the humanities and social sciences.

10-11 Carlton House Terrace, London, SW1Y 5AH

www.britishacademy.ac.uk 